\title{
REGARDING THE WAY-FINDING HABITS OF THE SIBERIAN PEOPLES, CONSIDERING THE KHANTS AS AN EXAMPLE
}

\section{Art Leete}

According to J. Derrida, meanings that are separate and not related to any sign system, refer to an impaired layer prior to a language or sign system (Derrida 1995: 39-40). Pre-alphabet meanings (i.e. meanings that existed before a language or sign system) can be related to any human action in the landscape, including way-finding.

This article examines the Khants' and other Siberian peoples` orientation skills and landmark systems. Those data that have not appeared in previous articles by this author will be highlighted (Leete 1995a, 1995b, 1996). For the Khants themselves, there is no hierarchical difference whether to orientate themselves using natural objects or other ways of way-marking, i.e. by breaking tree branches, cutting notches and signs on tree trunk etc. For a researhcer, such classification may prove useful. In the case of orientation taking place by means of environmental differences, without the help of man-made landmarks, this refers to the original layer of a culture. The use of landmarks is an aspect in the development of communication strategies and sign systems.

\section{Orientation by means of environmental differences.}

Peoples living in the tundra and taiga belts get a sense of orientation with the help of various natural objects, such as the Sun, Moon, stars, wind, rivers, trees, and many others. There are an infinite number of such orientation strategies. The available data on the subject have been highlighted in an earlier paper by the author (Leete 1995b). So, in the present article these will not be addressed. Rather, some additional data on the subject will be provided.

The natural objects chosen as landmarks need not be among the most prominent and eye-catching objects in the landscape. However, this would not help when showing the way to a stranger by describing the environment. In 1994 during the fieldwork with the Khant and Nenets peoples, in the Priuralski region, such orientation strategies are interpreted as follows:

In Laborovaya village I was shown the way (by a Nenets person) as follows: When I arrived at the peak of a particular hill, I would see the first conical tent. So we wandered around the lakes until we finally arrived. I... ( A Nenets) Prokopi then showed us another hill, and at the peak of it we would see another conical tent. (TAp 900: 56).

Also, natural phenomena can be used as landmarks. For example, the main wind direction, tree trunks which are slightly covered with moss on the northern side, and the fact that they have fewer branches on the northern side, as well as the position of ant-hills in relation to the quarters of the horizon (Leete 1995b: 50-51). Or else the fact that some West-Siberian swamps do not freeze in the winter and above the water there forms a mist (Lutski 1947: 93, 98).

The peoples living in the tundra belt Photo. 1 do not consider orientation in the homogeneous taiga belt possible, as one cannot see anything there. On the other hand, the peoples living in the wild forest are not able to orientate themselves in the bare tundra environment, as there are no basic landmarks (Leete 1995b: 51). Yet the taiga environment is not homogeneous overall. The Khants living in the area around the Pim River have surroundings which are more diverse (with woods, 
swamps, lakes, rivers and streams in it), Photo. 2 , consider the forests of the taiga belt to be a homogeneous environment where there are no prominent objects to spot. A. Kanterov (44), a Khant, living in the region around the Ai-Pim River, explained this as follows: "There are thick forests. You go on and on .There are no differences, it's all the same everywhere" (EA, Leete 1995).

According to A. Kanterov, in the taiga zone, there is nothing to do with the wind direction, as it always changes. In the region around the Pim River, where there are fewer trees, the wind blows in the same direction all day long. However, there is no constant wind direction (EA, Leete 1995).

In the thick forest in the region around the Lyamin River (next to the Pim River) there are, according to A. Kanterov, "closed days", when there are neither wind nor sunshine, these days are misty. In these days people get lost immediately in the taiga belt. There are no landmarks for assistance. One can move around and return to one's own footprints, wondering who has already been there. Later one realises that the footprints are one' own. Even experienced hunters may sometimes get lost in the closed days. There are no landmarks whatsoever..." (EA, Leete 1995). However, in the thick taiga forest people can find their way with the help of surface forms. One more citation by Aiser:"It is convenient to orientate oneself in the thick taiga forest. I frequently go there. In the middle of the forest you must look for the parts that are slightly slanted, and go along them. Wherever they turn, you must go along them. Later you will come to some stream. So you will manage. Although there is no Sun you come to a riverside. Then you will see - there is a big river" (Leete 1995).

\section{Using landmarks}

\section{Sounds}

According to the data collected by H. Sarv, in Yuilsk village by the Kazym River, some Khants found their way to the hunters` seasonal dwelling place when hearing dogs bark (TAp 678: 12).

In 1995 by the Ai-Pim River we once had to go from Aiser`s home to Jasha's, his brother, over the swamp. When Jasha's family heard that we were on the way, (the dog named Sharik did not want to leave the company of anthropologists, both we and Aiser shouted at it loudly), so they knew that we were coming. In a short time they realised that we should be quite near already, and gave a motorbike signal, for they thought that we may otherwise get lost (TAp 901: 36-37).

It may be that there are a variety of possibilities for orientating oneself using sounds, however, this aspect has not deserved enough attention during fieldwork.

\section{Footprints.}

According to V. Chernecov, a Khant or Mansi hunter follows the traces of animals, so as to be related to them. Traces have contours characteristic to the animals who left them, and also, traces have the smell of these animals. People can guess by the traces what state animals are in, how they behave, and what their intentions are," (Chernecov 1971: 86). 
By the Ai-Pim River, Jasha Kanterov`s wife Galya reported that in the summer a Khant hunter, when lost, can follow the routes of reindeer herds. He should follow more recent traces which definitely lead to a seasonal dwelling place, as on mornings reindeer go near fire to protect themselves from mosquitoes and midges (FM 1995). According to H. Sarv, in Yuilsk village by the Kazym River, the routes of reindeer herds (in addition to dogs` bark) showed the vicinity of human settlement (TAp 678: 12). However, A. Kanterov reported that it is not possible to orientate oneself using reindeer traces (EA, Leete 1995).

According to S. Lutski, to find traces of animals, one needs special skills and experience handed over from one hunter to another. So, it is known, for example, that hares do not move through thick snow, rather, they make routes along which they move. Also, it is known, which felled trees sables use for crossing rivers (Lutski 1947: 103). Hunters also know in which places otters and musk rats mostly make their routes when moving from one water to another. A. Kanterov set traps to narrow and shallow routes between clusters of grass along which they were supposed to move from one lake to another (TAp 910: 22, 23). By the Pim River a Khant, Vyatsheslav Pessikov, showed which felled trees, rotten from the inside, ducks use for building nests. Inside such trees one can find duck eggs (Leete 1994: 34). Also, some other aspects may inform about the routes and locations of game, such as their food supplies ( Yelpin 1928: 10).

The Khants living around the Salym River, Yugan River and partly around the Pim River, have used skis with carved backs. This detail enabled determination of ownership (Lukina 1985: 22). A Khant fairy-tale tells how, fearing that a snowstorm would erase the traces, long stripes along the traces were drawn in the snow (Mify 1990:188).

According to A. Kanterov, when one has lost orientation, the last chance would be to follow one's own traces (EA, Leete 1995).

In literature there are sporadic data regarding other Siberian peoples` way-finding by footprints. R. Its writes about the Kett pepole: "My path crossed with a ski route of wide skis covered with leather. By the trace of the stick's ring I realized that they belonged to Harlampi Petrovitsh (Its 1990: 155-156).

The Enets people, to catch a thief, measured the traces of his dogsleigh using a stick. Then, they looked for it, and its owner turned out to be the thief (Dolgikh, 1962: 82-83). The Nenets have used a similar practice for catching a thief (Istotshniki 1987: 106).

The Yakut heritage says that when throwing things into the river down the current, people inform relatives about the hero`s arrival (Salve 1995: 116).

\section{Branches}

The Khants living in the region around the Vasyugan River marked their way by putting moss on branches, or wiping off fresh snow (Kulemzin, Lukina 1977: 116). There are some instances of placing moss on branches around the Yugan River (Bakhlykov 1992: 21) and the Pim River (FM 1991, 1995). Turning points were marked by bottles on branches (FM 1991, 1992). 
To point the direction, the Khants break branches with the tops along the direction of the route. In the region around the Vasyugan River, people said that the main God, Torum, used broken branches to show that these were peoples paths, whereas the rest were for spirits and fairies (Kulemzin \& Lukina, 1977: 116).

Branches stuck into the snow also served as landmarks. They may have been slanted along the direction of the path. They were placed in line with an interval of some tens metres. When paths went in various directions, unnecessary paths were covered with branches. The direction was also pointed by branches stuck into the snow, with pieces of birch bark on top of them (Kulemzin, Lukina, 1977: 121). The Khants living in the region around the Kazym River said that sometimes the path through the swamp was not marked in the winter. Should a snowstorm erase traces, men just ran before a snow-mobile to find the way (FM 1992).

In the region around the Pim River the author saw three branches stacked and covered with moss to mark the beginning of the route near a lake (FM 1992). A. Kanterov marked the location of a musk rat trap by sticking a branch into mud (TAp 901: 23).

The Evenk people had signposts ('huva') made of battens and sticks. These signposts pointed along the direction of the route, and had places crossing the river on them. On the opposite river bank there was another signpost to point the direction of the route (Horoshikh 1950: 57, Fig 1). In the winter hunters left branches or sticks on their way in the snow that were slanted along the direction of the route (Horoshikh 1950: 57).

Fastening branches to notches on tree bark slanted toward the direction of the route was also practiced by the Khants living by the Pim River (EA, Leete 1995).

\section{Trees}

Young trees were cut down two-fold, with tops pointing along the direction of the route (FM 1992, Photo. 3).

According to a Khant song, young felled trees are placed on the groung along the route (OVE 1: 373). In Khant songs there are several descriptions of marking the way and making signs on tree bark (Eva Schmidt $>$ A. Leete, oral report). The felled trees were certainly used and warned people against quagmires, for example (Gorodkof 1911: 27).

According to V. Chernecov, as with branches, so trees were stuck into the snow slanted along the route. The Mansi peoples made a 'hand mark'(tribe's mark) on such trees. This gave information to people coming after them (Istotshniki 1987: 43). There is an instance that the Mansi people left a reindeer, harnessed to a conical tent, wandering near the route should it be tired or injured. By the route a tree with a hand mark was stuck into the snow. This helped to find it afterwards. At the same time, this informed passers-by to whom the reindeer belonged (ibid.).

To fix the location of a conical tent or dwelling area, the Nenets people made a long batten for driving a reindeer set ('horei') on the top of the nearest hill. To the batten a white fur was tied (Homitsh 1986: 17). According to V. Cernechov, the Nenets people living in the Yomay peninsula used to place piles of reindeer horns as signposts on tops of hills (Istotshniki 1987: 125). 


\section{Notches}

By the route, some bark was cut from tree trunks with an axe. Nowadays this is the main way of marking one's route among the Khant people.

A tree trunk can be notched on one, two, three, or four sides. Trees with notches on two sides can determine the direction of the route more exactly. Usually the hypothetical line crossing the two notches is parallel with the route. Before turns, the position of notches changes in accordance with the direction of the turn (Leete 1994: 25). On trunks growing into one or those growing close together, notches are cut next to one another pointing similar directions. This is supposed to ease determination of the exact direction of the route (FM 1991).

Trees are notched as frequently as one could always see the next one. Near Hullor village by the Kazym River, there is a path of 1.8 kilometres with 144 notched trees on it (among which 85 are with notches and 59 with signs, i.e. a marked tree every 12.5 metres) (Leete 1994: 25).

According to J. Kanterov, a boat harbour or place for boat landing can also be marked. Should any strange Khant pass by along the river, he will notice the trees with notches. He lands knowing that there is human settlement nearby (EA, Leete 1995). J. and G. Kanterov said that notches are also made on tree bark when the path takes to a rivierside. Also, notches were made when the boats made by hollowing a tree trunk were dragged along the ground by passing bends in a river. A. Kanterov said that instead of rowing 3 - 5 kilometres, one must drag the boat along for only 100 200 metres (EA, leete 1995). At the beginning of this century, the Khants also had fixed places for dragging their boats on their way to dragnet fishing zones (Sirelius 1983: 70-71). A. Kanterov remembers using these dragging places when on their way to a bigger settlement (EA, Leete 1995). Today the Khants cover longer distances by motorboat. By the Pim River the boats made by hollowing a tree trunk are dragged along the ground only near the seasonal dwelling place around swampy lakes (TAp 910:24). According to a Khant folk song, notches marked the places where one could cross the river in the winter (OVE 1: 427).

By the Pim River, a Khant, Volaksi Kanterov, marked trees by the path for motorbikes (EA, Leete 1995). Aiser Kanterov marked the location of a new winter dwelling place, and also the way to it not yet trodden (TAp 901: 22). Similarly, A. Kanterov had marked the path from the deserted autumn settlement (they deserted it when Aiser`s father Aleksander died) to a new one where Aiser's family and a widow settled down (TAp 901: 20-21). According to H. Sarv, the Khants living in the northern region have marked the path before the regular resettlement every 2-3 days (TAp 678: 16). Timofei Kanterov made notches on the trees that he was going to cut down when building a winter settlement (TAp 901:33).

Around the Lyamin River branches are partly cut off (near to the top of a tree). This indicates the beginning of a path for those who are on the opposite bank of the river (FM 1991; EA, Leete 1995).

In the 19th century some hunter communities from the Petshooramaa region hunted in the regions to the east of the Urals, thus moving 200-300 miles away from their homes. They found their way back by following notches cut on tree bark (Passetsky 1970: 144). 
The Evenk hunters have used removed parts on tree barks as landmarks. Such marks were called 'il kon'. In the taiga belt trees are marked by the path every $20 \ldots 60$ metres or more depending on the thickness of the forest, as well as the degree of visibility and the contours of the landscape. To make it easier, they stuck small sticks or branches in the notches. These sticks pointed at the nearest subsequent landmark (Horoshikh 1950: 57; Fig. 1).

Sometimes these landmarks indicated the duration of the hunters' staying away. "When a hunter goes far from a dwelling place, he sticks a long stick (honin-huva) into a batten ('huva'), or fastens a stick to it. When he does not go too far, he puts a small stick (urumkun-huva) into the batten. When the hunter hopes to be back soon, he fastens the small stick to the long one, with the small one pointing in the opposite direction (ibid.: 58; Fig. 2). The number of days the hunter is going to be away is indicated by rings made by weaving twigs of willow, birch and bird cherry together (ibid.; Fig. 3Figure 3). People, reindeer and dogs who are with the hunter are drawn on tree bark using charcoal (ibid.; Figure 2). Should any member of a family fall ill, spots were made on tree bark using characoal, with a person on either one' side or the reverse on it. Should any relation die, this person was drawn with the face downwards (ibid.: 58-59; Ivanov 1954: 123-124).

\section{Signs cut on tree trunks}

Signs ('juh pos' in the Khanty lng.) are cut both on tree bark and the tree trunk (where the bark has been removed). These signs give additional information to those who pass by. When anybody wants to provide more exact information about himself, the family mark is also cut there besides notches.

At the beginning of this century, a Mansi hunter, when moving around in the Ural mountains cut "the patterns similar to those that were on his hands" into tree bark. According to some Russian ethnologists, this was done to help to find hunters who got lost. (Ivanov 1954: 45; Rudenko 1929: 15). In the region around the Kazym River, a Khant Andrey Lozyamov, explained this as follows: "Later it is good to see where I have been", (Leete 1994: 26, 28). This can be true, as around Hullor village, the frequency of landmarks on some paths is far higher than is necessary for way-finding.

Nowadays there are some elderly Mansi men who make their handmarks in all the places where they stop when hunting or fishing (Zaplatin 1992(9): 58).

There are also some accounts that the Khants marked trees to indicate where they have stopped, or as they themselves say, where they have had tea (Leete 1994: 26; EA, Leete 1995; Photo. 4). Also, they used to mark trees near the traps for catching capercaillies (Leete 1994: 30; Photo. 5).

The Mansi marked the places where they stayed overnight by making their family marks on either side of a tree, and on the side of the path they made as many notches as there were people and dogs with them. The three big trees (two cedars and a spruce) under which they slept, got new names (Istotshniki 1987: 264). According to Nosilov, sometimes they cut the face of the spirit near the notches. The faces of the people and the dog cut into the tree bark were dedicated to this spirit (Karjalainen 1918: 170; Ivanov 1954: 20).

At the beginning of the 20th century there was a custom among the Mansi living in the southern regions that when having a wedding party in winter, a bride was taken to the groom's home by a cart. "On the way there special signs were made on trees indicating the direction along which the 
bride was taken. The same happens when the bride is taken away in summer along the river". (Infantyev: 1910, 55-56).

During the bear festival the Mansi also cut signs on tree bark. The signs were cut on the side of the path along which the killed animal was taken home. These signs indicated the number of hunters and dogs, as well as how many bears they killed. They cut the signs, using a knife, several times on their way (Saynakhova, 1990: 134).

The Khants living in the region around the Kazym River hold that a person going to the cemetery for the first time, makes a notch on a tree (FM 1992).

In more recent times initials also have been carved into tree bark (ibid.: 26). The Khants themselves consider the use of the Cyrillic alphabet on tree bark to have started in the 1970s. However, fieldwork materials indicate that it had started several decades earlier (ibid.).

The Yakut people used to provide information for those who come after them. They made signs on tree trunks using charcoal. The information could be about where they stayed overnight and what they left behind. Those coming later had to take along the things and wandering reindeer with them (Gribanovski 1946: 283).

On some anthropological interpretations regarding traditional orientation strategies of some Siberian peoples.

In literature the data regarding marking one's way are sporadic and vary considerably in time, as well as from region to region. This can be understood, as for the Khants way-finding is not an independent activity. One cannot have an overall interpretation of marking one's way. The fieldwork materials that are available mostly cover few regions only (e.g. around the delta of the $\mathrm{Ob}$ River and its tributary rivers, the Kazym River and the Pim River).

Ethnologists have until now interpreted visual perception and orientation skills of the peoples living in the tundra and taiga belts by intuition, (for example, interpretations offered by Freuchen 1963: 21-22; Alekseyenko 1986: 81; Lukina 1986: 127; Fyodorova 1986: 143; Homitsh 1986: 17; Rolnik 1986: 187). They have all been examined in the previous work by this author (Leete 1995b, 1996). This may be considered to be a typical mistake made by applying only qualitative methods to ethnological studies (see Tulviste 1984: 33-35). Thus, a researcher believes (taking it for granted) that, for example the Kett, Nenets or the Eskimo people interpret the environment in a descriptive way. However, when providing loose interpretations and statements entering the field of psychology, they do so without trying to offer any reasonable explanation for such phenomena. They say this extraordinary visual sense is an inborn skill and is handed over from generation to generation. Here comes an extract typical of romantic and superficial writing: the Evenk hunters are highly sensitive to the objects that are characteristic of the tundra environment. When an Evenk goes once along the taiga path, boats along a curving taiga river, or else finds a hardly noticable ford, he will remember all the details of the environment, and also all the different path directions, (Horoshikh 1950: 57).

In this case it seems to the author that the Evenks remember all the aspects of their surroundings (as it is natural to do when living in the same environment all the time). However, when modelling sign 
systems "this would not be enough," (Öim 1974: 63)). In reality, the process of storing things in the memory is not that uniform and simple. Anyway, Horoshikh has not offered any explanation for his hypothesis, and thus we do not have much to go on when examining traditional orientation skills. There are quite a number of incidents of the phenomenon where the supporters of a particular culture cannot explain the need for orientation skills: they take it for granted, (Middendorff 1987: 88; Leete 1955b: 54-55). Yet for researchers, following a similar pattern would probably be a mistake.

Although this paper deals with general culture-bound orientation skills, within even one region there can be several orientation strategies, (even though that there is not enough proof). It is for every member of the Khant community to decide which strategy he or she chooses, and to consider other orientation strategies to be nonsensical though approved within the same region. So, the Khants living in the region around the Pim River use reindeer footprints for way-finding in the morning somewhat differently (EA, Leete 1995; above). Also, the Khants living in the region around the Kazym River have cut signs on trees in a different manner. In Hullor village, near its tributary the Amnya River, most of the signs are cut on the notched parts of tree trunks, whereas in Yuilsk village most of them have been cut on tree bark (FM, 1992). What a particular supporter of the community chooses may depend upon his or her understanding, as well as sympathies of the community as a whole. Also, this may be caused by the fact of what kind of objects are there in a particular environment, or is there any need for the use of traditional orientation skills. People may be skilled in doing so, though they may not be in use any longer (Tomilov 1986: 56).

There is no hierarchical difference between not marking one's way and marking it in any way imaginable. Reported accounts do not always reveal what the process of making landmarks was like. Paths need not always be marked, people may just know them. During the fieldwork of 1992, it appeared that there was a path along which one could go on foot from the city of Beloyarsk to Yuilsk village in the Beryozovo region. Also, there were paths from Yuilsk village to the seasonal dwelling places by which there were huts for staying overnight (FM, 1992).

Marking one's way depends on some more aspects, such as the seasons. According to Aiser Kanterov, in summer moss is often used for marking one's way near the Pim River. They used to cut a small piece of moss using a knife, and place it on a branch. "In winter they make notches on trees, place sticks and cut off branches, so that they can be seen. Branches are cut from big trees so that to be seen from long distances, a kilometre or so," he said, (EA, Leete 1995, above).

Orientation does not depend only on the details of the landscape or the way of marking one's way. A Khant, Dmitri Pokatshev, living in the Russinskye village by the Tromygan River told the following story:

Once my uncle's reindeer wandered off. The uncle followed the same direction which the reindeer had taken, but he found no footprints. Then he took out an axe and started to say mantras. He at once realized where his reindeer was (EA 234: 121). Orientation strategies in relation to the traditional conception of interpreting the landscape of the Khants and Samoyed peoples have been discussed further in some other papers (Leete 1996). The possible relationship of the traditional conceptions of modelling the landscape (both vertical and horizontal) cannot be explained overall. Nowadays, when moving in the landscape, the Khants probably use less complicated strategies than those of interpreting the events afterwards. In the latter case the traditional conception of interpreting the landscape is more stressed, (ibid.). 
Also, the socialization process, economic systems and sex roles have been suggested as affecting the process of acquiring orientation skills and visual perception. However, no one has been able to estimate the exact involvement of each factor, (Cole \& Scribner 1977: 109-112). Perhaps traditional way-finding habits cannot be explained according to their single components, as they make up one of the most archaic and inseparable component of the emic worldview as a whole.

Translated by Epp Uustalu.

\section{Photographs and figures}

Photo. 1 - A view of the tundra landscape. On the Shtshutshye River near Laborovaya village, Priuralsky region. In front: reindeer herders' cemetery where people are interred above the ground. Photograph by Art Leete 1994;

Photo. 2 - A view of the taiga landscape on the Pim River, Surgut region. Photograph by Art Leete 1995.

Photo. 3 - A tree cut down pointing along the direction of a path by the Kazym River near Yuilsk village, Beryozovo region. Photograph by Art Leete 1995.

Photo. 4 - A sign on a tree trunk near a fireplace, made by the Khants by the Kazym River near Hullor village, Beryozovo region. There have been two people, the Peskofs' family mark has been engraved there. The meaning of the large zigzag shape is unknown. Photograph by Art Leete 1992. Photo. 5 - A sign on a tree trunk near the trap for catching capercaillies by the Kazym River near Hullor village, Beryozovo region. At the centre: a sign indicating the traps, whereas the notches around it indicate that both to the left and right of the tree there are two lines of traps. Photograph by Art Leete 1992.

Figure. 1 - Marks (il'kon) cut into a tree trunk by the Evenks, used as signposts. Made by P. Horoshikh (1950).

Figure. 2 - A signpost made of sticks (honin-huva) by an Evenk hunter pointing along the direction he went, and also indicating that he will be back soon. The hunter, as well as reindeer and dogs with him are drawn on the tree bark using charcoal. Made by P. Horoshikh (1950).

Figure. 3 - The signposts pointing along the direction the Evenk hunter had taken. 15 rings indicate the number of days the hunter is planning to be away. Made by P. Horoshikh (1950).

\section{Literature}

Alekseenko, J. 1986. Promyslovaja kul'tura korennogo naselenija Turuhanskogo regiona. Kul'turnyje tradicii narodov Sibiri. Leningrad, pp. 57-94.

Bahlõkov, P. 1992. Istorija, byt, kul'tura juganskih hanty. Jugra, Hanty-Mansiisk. nr. 3, s. 21-28; nr. 4, s. 1827; nr. 5, s. 15-23; nr. 6, s. 19-24; nr. 7, s. 20-23.

Cole, M., Scribner, S. 1977. Kul'tura i myshlenije. Psikhologiczeskij oczerk. Moskva.

Derrida, J. 1995. Positsioonid. Tallinn.

Dolgihh, B. M. 1962. Bytovye rasskazy entsev. Trudy Instituta Etnografii. n.s., t. LXXV. MoskvaLeningrad.

Fjodorova, J. G. 1986. Elementy tradicionnogo v sovremennykh hozjaistvennykh zanyatiyakh mansi.

Kul'turnye tradicii narodov Sibiri. Leningrad, pp. 139-156.

Freuchen, P. 1964. Kütid Melville'i lahes. Tallinn.

Gorodkov, B. 1911. Poezdka v Salymskii krai. Jezhegodnik Tobolskogo muzea. vyp. XXI, lk. 1-100.

Gribanovski N. N. 1946. Svedeniya o pisanicakh Jakuti. Soveckaya Arheologiya. VIII, pp. 281-284.

Homich L. V. 1986. Kul'turnye tradicii v trudovoi deyatelnosti i materyal'noi kul'ture olenevodov severa 
Zapadnoi Sibiri. Kul'turnye tradicii narodov Sibiri. Leningrad, pp. 12- 41.

Horoshihh, P. P. 1950. Put'evye znaki evenkov-okhotnikov (Iz materyalov po etnografii evenkov r. Nizhne Tunguski). Kratkiye Soobshczenia Instituta Etnografii imeni N. N. Miklukho-Maklaya. Moskva-Leningrad, t. 10, pp. 57-59.

Istotshniki 1987 = Istoczniki po etnografii Zapadnoj Sibiri. Tomsk.

Jelpin A. 1928. Kak my poimali i soderzhali lisyat. (Iz zhizni ostyakov Kondinskogo rayona). Taiga $i$

Tundra, Leningrad. nr. 1, pp. 10-12.

Infantyev, P. P. 1910. Putesestvije v stranu vogulov. Sankt-Peterburg.

Its, R. 1990. Shepot Zemli i molczanije Neba. Etnograficzeskie etyudy o tradicionnykh narodnykh

verovaniyakh, Moskva.

Ivanov, S. V. 1954. Materyaly po izobrazitel'nomu isskustvu Sibiri XIX - naczala XX vv. Trudy Instituta

Etnografii, n.s., t. XXII. Moskva-Leningrad.

Karjalainen, K. F. 1918. Jugralaisten uskonto. Suomensuvun uskonnot 3. Porvoo.

Kulemzin, V. M. \& Lukina, N. V. 1977. Vasyugansko-vahovskie hanty v konce XIX-naczale XX vv. Tomsk.

Leete, A. 1992. Obiugri märgipärimuse aspekte. Seminaritöö. (Käsikiri). Tartu.

Leete, A. 1994. Handi piltkiri puutüvedel. Peaseminaritöö. (Käsikiri). Tartu.

Leete, A. 1995a. Handi puumärkide mõistmise "mõistmine". Eksitaja. Pro Folkloristica 3. Tartu, pp. 29-32.

Leete, A. 1995b. Arhailine kiri. Orienteerumisest taiga- ja tundravööndi kultuurides. Vikerkaar, nr. 12, pp.

50-57.

Leete, A. 1996. Taiga- ja tundrarahvaste ruumitundmisest seoses orienteerumisviisidega. Eesti Rahva

Muuseumi aastaraamat, $\mathrm{nr} 41$. Tartu.

Lukina, N. V. 1985. Formirovaniye material'noi kul'tury khantov. Tomsk.

Lukina, N. V. 1986. Kul'turnye tradicii v hozaistvennoi dejatel'nosti khantov. Kul'turnye tradicii narodov

Sibiri. Leningrad, pp. 121- 138.

Lutski, S. L. 1947. Geograficzeskie oczerki russkoi taigi. Moskva.

Middendorff, A. Th. 1987. Reis Taimõrile. Tallinn.

Mify $1990=$ Mify, predaniya, skazki hantov i mansi. Moskva.

OVE I = Steinitz W. 1975. Ostjakologische Arbeiten band 1. Ostjakische Volksdichtung und Erzählungen

aus zwei Dialekten Texte. Budapest.

Passetski, V. 1970. Eestist pärit Arktika-uurijad. Tallinn.

Rolnik, I. A. 1986. Nacional'nye tradicii i hudozhestvennoe tvorczestvo neneckikh detei Jamala. Kul'tura narodnostei Severa: tradicii i sovremennost'. Novosibirsk, pp. 182-189.

Rudenko, S. 1929. Graficzeskoye isskustvo ostyakov i vogulov. Materyaly po etnografii. t. IV, vyp. 2, pp. 13-40.

Salve, K. 1995. Kangelassugu Siberist läänemeresoomlasteni. Ajalaval. Helsinki-Tartu, pp. 112-127.

Sainahhova, N. V. 1995. Manside usundist. Rahvausund tänapäeval. Tartu, pp. 354-356.

Sirelius, U. T. 1983. Reise zu den Ostjaken. Helsinki.

Zaplatin, M. 1992. Tapsvatpaul': zimnije dni. Jugra, Hanty-Mansiisk, nr. 9, pp. 56-61; nr. 10, pp. 58-61; nr. 11, pp. 59-62; nr. 12, pp. 58-61.

Tomilov, N. A. 1986. Osnovnye tendencii etnokul'turnykh processov u korennykh narodov ToboloIrtyshkogo regiona na sovremennom etape. Kul'tura narodnostei Severa: tradicii i sovremennost'.

Novosibirsk, pp. 49-59.

Tshernetsov, V. N. 1971. Naskal'nye izobrazheniya Urala. Arheologiya SSSR. Svod arheologiczeskikh istocznikov, vyp. V4-12, cz. 2, Moskva.

Tulviste, P. 1984. Mõtlemise muutumisest ajaloos. Tallinn.

Õim, H. 1974. Semantika. Tallinn. 